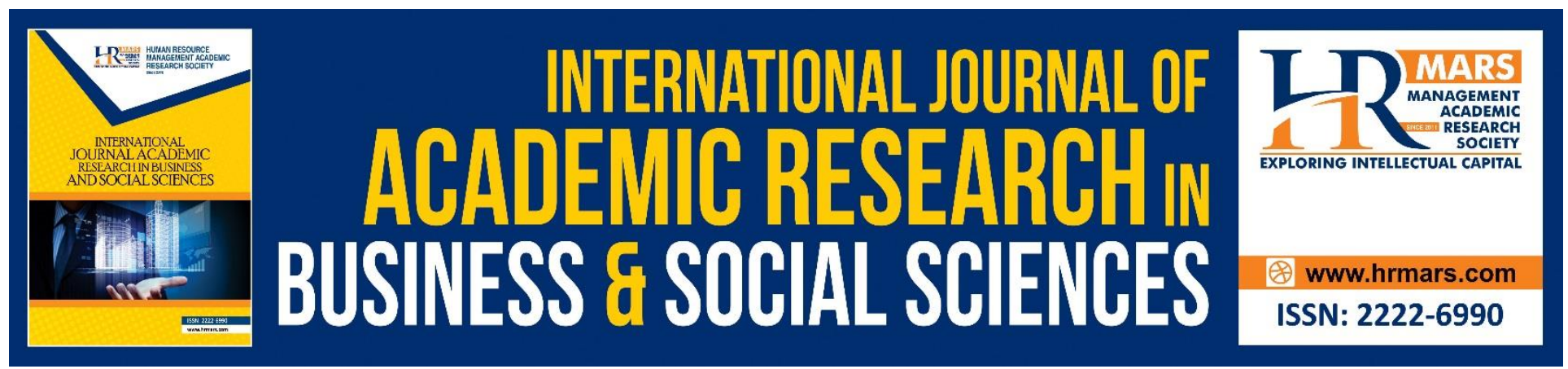

\title{
Police Officer's Commitment towards Community Policing in Malaysia: Instruments Development and Validation
}

Abdul Hadi Sulaiman, Hanina H. Hamsan, Aliyu Yero \& Jeffrey Lawrence

To Link this Article: http://dx.doi.org/10.6007/IJARBSS/v11-i15/10650

DOI:10.6007/IJARBSS/v11-i15/10650

Received: 06 May 2021, Revised: 15 June 2021, Accepted: 03 July 2021

Published Online: 27 July 2021

In-Text Citation: (Sulaiman et al., 2021)

To Cite this Article: Sulaiman, A. H., Hamsan, H. H., Yero, A., \& Lawrence, J. (2021). Police Officer's Commitment towards Community Policing in Malaysia: Instruments Development and Validation. International Journal of Academic Research in Business and Social Sciences, 11(15), 245-261.

Copyright: (c) 2021 The Author(s)

Published by Human Resource Management Academic Research Society (www.hrmars.com)

This article is published under the Creative Commons Attribution (CC BY 4.0) license. Anyone may reproduce, distribute, translate and create derivative works of this article (for both commercial and non-commercial purposes), subject to full attribution to the original publication and authors. The full terms of this license may be seen

at: http://creativecommons.org/licences/by/4.0/legalcode

Special Issue: Empowering Youth and Community Wellbeing for Sustainable Development, 2021, Pg. 245 - 261

http://hrmars.com/index.php/pages/detail/IJARBSS

JOURNAL HOMEPAGE

Full Terms \& Conditions of access and use can be found at http://hrmars.com/index.php/pages/detail/publication-ethics 


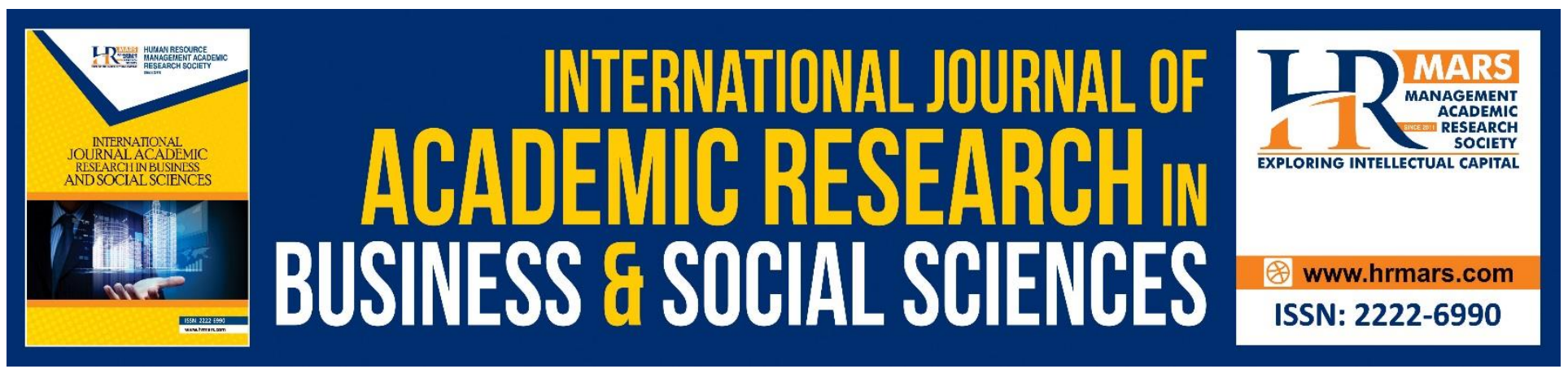

\title{
Police Officer's Commitment towards Community Policing in Malaysia: Instruments Development and Validation
}

\section{Abdul Hadi Sulaiman ${ }^{1}$, Hanina H. Hamsan ${ }^{1,2}$, Aliyu Yero ${ }^{1}$ \& Jeffrey Lawrence ${ }^{1}$}

${ }^{1}$ Institute for Social Science Studies, Universiti Putra Malaysia, 43400 UPM Serdang, Selangor Darul Ehsan, Malaysia, ${ }^{2}$ Faculty of Human Ecology Manusia, Universiti Putra Malaysia, 43400 UPM

Serdang, Selangor Darul Ehsan, Malaysia

Email: hanina@upm.edu.my

\begin{abstract}
While many researchers have shown that commitment to task is vital for the success of organizational goals. However, the question still remain to what extent can we measure commitment especially to strategy such as community policing within police organizations. Importantly, variations exist depending on societies and cultures. These factors may influence measurement and results. The study therefore set out to investigate factors that are related to commitment of police officers in Malaysia towards community policing using elements of the job characteristic model of community policing, in the end instrument was developend and validated reflecting Malaysian context using structural equation modeling. A total of 197 police officers were surveyed in the state of Malacca with a 45 item instrument developed. Findings indicated that all items (management support, job satisfaction, community support and co-worker support) pass the convergent validity ( $\mathrm{AVE}=>0.50)$. The reliability for each construct also passes the .07 cronbach alpha. The above instrument has the ability to test the level of commitment within Malaysian context and can be applied in other context after confirming cultural variation.
\end{abstract}

Keywords: Commitment, Community Policing, Royal Malaysian Police, Organizational Success

\section{Introduction}

The thought of community policing in Malaysia began far back in 1967 when the Inspector General of Police (IGP) Tan Sri Salleh Isma'il acknowledged the requirement for greater engagement between Royal Malaysian Police (RMP) and also the people for that promotion of peace and security. Malaysian model of community policing was lent from the Japanese KOBAN system (KO-change and Prohibit-meaning guard), that means law enforcement are policing on the street so that public can approach them and assist on matters of inquiry and breach of peace they have to report which was actually effective as observed later by Bayley (1994). Malaysian journey towards the path of engagement and collaboration between police and individuals; began from a process which came be 
referred to as system Salleh. All this while it wasn't known as community policing until in 2007 when the programme was formally brought on track and named. Several nations were also following suit particularly in Asia for example Singapore. However, community policing was flagged off with so many challenges especially of implementation.

The implementation of community policing begins in the police organization then lower to folks, and with no full cooperation and commitment of officer's and individuals to the programme it's condemned to fail, this concept is corroborated by Lucas et al., (2003) who observed that the officer particularly is within the best position to apply community policing, his or her acceptance and commitment in the direction of the tenants of community policing is an extremely important problem to deal with. The programme certainly faced lots of challenges; for example cultural resistance. Tilley (2003) recognized "cultural resistance" among many recurring challenges facing community policing especially by officer's which prevent commitment. For Tilley, when officer don't accept or have confidence in the drive simply because they think that maintaining traditional regulating methods of pressure and facing crime hard ought to be maintained. This inform the desire to study and investigate the level of commitment of officials towards community policing to ensure that a much better understanding is going to be established regarding what factors would be related to commitment towards community policing in Malaysia.

Community policing represents a new strategy in crime prevention which include lots of new methods that need tremendous transformation to impliment, it represent a hybrid of traditional policing; in addition to modern policing techniques that will surely come because of so many challenges.

Regardless of the success and effectiveness of community policing in variety of societies around the globe, it's still not obvious what factors are generally regarded and applicable globally to officer commitment; so what are the specific factors that push officials to simply accept or reject community policing in Malaysia and how similar these factors rhythm with othe parts of the global community?. The study seeks to identify some core variables which are based on police commitment to community policing in Malaysian context and to ensure that as implementation work is on course, policymakers will benefit from this study outcome and pay attention to specific variables for the effective implementation of the programme.

This will be relevant because individuals who create guidelines aren't individuals who put them into action on ground (Lucas et al., 2003). This therefore implies that if individuals who're to apply community policing in Malaysia don't accept and invest in the brand new strategy, then the programme is definite to fail.

Basically therefore, low or lack of commitment from Malaysian police towards community policing suggests an issue for urgent attention to promotion of peaceful coexistance in Malaysia. Officer's acceptance from the tenets of community policing is a vital objective by management as these officials are in the very best position to apply these programmatic changes. While there's common acceptance and knowledge of the paradigm in the administrative level, many community policing programs haven't been fully understood or recognized in the line level (Durmaz, 2007). 


\section{Objectives}

The objective of the study would be to identify variables that are based on Malaysian police commitment on community policing with a view towards comprehensive knowledge of the programme. Particularly, reliability and confirmatory factor analysis are going to be done on key recognized variables associated with police resolve for community policing.

\section{Characteristics towards Officer Commitment for Community Policing}

Taking advantage of the entire potential of officer's to ensure law and order is becoming probably the most constant problem of police organizations (Tankebe, 2010). For this reason police organizations view commitment as essential to ensure loyalty. By extension, Coser observed that "loyalty even when confronted with competing appeals remains vital for the prosperity of police organizations" (Peterson and Uhnoo, 2012). Through the years, there seem to be insufficient established definition among students on what commitment denotes, possibly this result in the multidimensional approach scholars adopt in construct (Meyer and Herscovitch, 2001). Even though commitment doesn't have universal definition, a detailed observation of numerous definitions discloses a core element including "extraneous interests that are associated with consistent type of activity and comes into being whenever a person constitutes a side bet", "a mental condition that binds the person towards an organization", "willingness of the individual to help with effort to enact the strategy" and "individuals motivation to work in a chosen vocation".

One element sticks out, that is mental and mind-set, i.e. mind set or mental condition that obliges a person towards a strategy. This signifies it does not matter the discernment commitment remains a mind set towards something and therefore, remains inside the individual under consideration. Community policing therefore being an ideology grew to become formed through the environmental factors within the police and also the people found themselves driven through the need to enhance the quality of life style and excellence of existence. Organizational commitment writings has stated numerous benefits and some restrictions. The idea of commitment within the place of work continues to be probably the most challenging and investigated concepts within the fields of management, organizational behavior and HRM (Cohen, 2003; Cooper-Hakim and Viswesvaran, 2005).

Community policing program achievements are, thus, proper to be based on the amount of interest and readiness for police to recognize using the fundamental concepts of community policing concepts that by their very character have cause changes to well-established police business and job constructing. Several studies on police working conditions claim that how police experience their job as well as their department, can greatly affect their relations using the public and the standard of police force service they offer (Brunetto and Farr-Wharton, 2003).

Measures of organizational commitment appear in three levels within the inquiry literature: individual worker demographic qualities, job-specific characteristics, and organizational qualities (Kristof-Brown et al. 2005). Individual worker qualities include sex, age, race, education, tenure, and supervisory status. Many of these qualities have been discovered to become connected with organizational commitment inconsistently. However, their overall impact seems to become small when compared with the outcome of job and organizational qualities (Kristof-Brown et al. 2005). Job qualities make reference to the standards defining the general work situation for that worker and 
can include job variety, job autonomy, job stress, and cognitive dissonance from role strain. These job features largely reveal an average effect on worker organizational commitment with greater amounts of occupation variation and autonomy, growing organizational commitment, and greater amounts of job stress and role discord lowering organizational commitment (Kristof-Brown et al. 2005).

\section{Job Satisfaction and Community Policing}

The change from traditional to community policing signals a significant effort to redefine the way a police agency works. (Ford et al., 2003) to become effective, progress to community policing needs a major change within the suitable focus of the police agency. This transformation in proper focus features a change within the underlying philosophy of policing, an enlargement from the domain considered highly relevant to regulating, and a general change in the way the police agency works internally within the department in addition to externally (Greene, 2000).

Prior studies have revealed that job satisfaction is connected with officers' attitudes toward community policing. Halsted and the co-workers (2000) discovered that officer's who're pleased with pay and benefits have optimistic approaches toward community policing. They contended that officer's notice that assets, for example pay and benefits emanate from community they serve. Officer's might think that their resolve for community policing is the best way to get reward in terms of pay and benefits. However, they measured officers' attitudes toward community policing by assessing the extent officer's are oriented toward service activities instead of assessing awareness concerning the perception of community policing. Lilley and Hinduja (2007) recommended that officer's who're pleased with their promotion possibilities may have an optimistic attitude toward community policing simply because they think that their efforts is going to be compensated through promotion. Pelfrey $(2004,2007)$ established that satisfaction with work positively influences officers' attitudes toward community policing. He contended that officials who're pleased with the work they do possess the chance to see the outcomes of the efforts. Officials may participate in efforts to apply community policing once they know their efforts is going to be compensated through the community. For example, Korean police satisfaction with promotion possibilities is positively connected with officers' attitudes toward community policing (Hwang and Woo, 2009). Hwang and Woo's (2009) findings are in line with Lilley and Hinduja's (2007) explanation that officials who're pleased with promotion may commit to the implementation of community policing.

\section{Management Support and Community Policing}

Top management support happens when an organization's greatest ranking professionals encourage their employees and give them the assets they have to attain the objectives and goals from the organization (Young and Jordan, 2008). Top management support is among the significant aspects of organizational culture upsetting employees' organizational efficiency (Somers and Birnbaum, 2000).

Management support is among the most significant factors for the effective implementation of community policing because management styles influence officers' attitudes toward community policing (Gonzalez and Guillen, 2008). When officials are treated as internal clients through continuous support, officials may have an optimistic attitude toward community policing (Adams et al. 2002). Moon (2006) contended that officials who've an optimistic attitude toward their top management may have positive visions on community policing. 
Rhoades and Eisenberger (2002) examined 70 studies and noted that management support relates to performance however mediated by jobsatisfaction. Employees who perceived that they're held in esteem in their organization or top managers may be happy with their job and much more productive. However, it's not obvious how top management support was evaluated within the literature. More focus ought to be put on such measurement.

Superficially, results from a multi-method research which focus on influence of officer and supervisor attitude towards community policing by Engels and Worden (2003) reveal that officers' awareness of the supervisors' focal points for problem fixing affect how long they spend performing these activities, even though their individual approaches toward community policing and problem fixing are weakly correlated using their supervisors' attitudes.

Additionally, communication with top managers affects officers' attitudes toward community policing. Kwak (2009) interviewed 917 officials in Columbia, and 72 percent from the participants labored within the patrol or traffic division. He discovered that communication with top managers was positively connected with officers' attitudes toward community policing. Furthermore, he questioned 18 officer's who implemented community policing. The outcomes from the interviews says officials who experienced good communication with top managers could implement community policing. The interviewees reported their encounters of communication with top managers affected their opinions about community policing. Their feelings of participation in decision-making brought for their active implementation of community policing. Nonetheless, the research was just restricted to one province of south korea.

Within the wider literature numerous studies demonstrate that the amount of organizational and managing support worker feels, their participation in making decisions, and the quantity of feedback received about job performance and job role, and influence whether an individual has low or high commitment for the organization or strategy of the organization.

\section{Co-worker Support and Community Policing}

Peer group attachment seems to become a serious issue in the area of policing as officers have maintained a strong and well-recorded sub-culture. Police officers confide on one another for his or her very safety. Additionally they share common beliefs and attitudes about themselves as well as their work, leading to close work solidarity among officers. This doesn't mean that police are identical. Social networks at the office influence how people fairly and subjectively experience their employment. A number of researches on police organizations have contended that employees' social network at the office modify the effective implementation of police work (Sutham and Sarit, 2005; Haley-Lock, 2007; Wuthichai, 2017). Officer's who have a very good relationship via their administrators and co-workers may work positively and also have positive attitudes toward community policing. Social network at the office is very important for the implementation of community policing due to the fact that it enable officials to talk with one another (Wilson and Bennett, 1994). However other research indicate that co-worker support will likely have negative impact on community policing, Park (2006) reported that that too much closeness at the office is adversely connected with officers' attitudes toward community policing. In addition, officers who have close associations with lots of co-workers are likely to possess an optimistic attitude toward community policing. They concentrate on internal work relations, but they're uninterested in 
engagements with the people. However, when co-employees accept the tenants of community policing chances are it will influence other co-employees to welcome the idea since peer views have impact on general thought of employees (Polzin and Brockman, 2002). However, questioning Park's idea, he probably overlooked the truth that opinions are produced, shared and recognized by officials when co-workers accept the philosophy of community policing.

\section{Community Support and Community Policing}

Existing literature on citizen attitudes toward community policing was largely along three angles. Some researchs looked into the attention and understanding of community policing from the public. For instance, according to Sulaiman et al., (2014) they discovered that community residents' in Malaysia perception and understanding about community policing was prudently associated with their status locally with community leaders getting more understanding than regular citizens, particularly senior citizens. Besides that, several indicator had been also discovered on citizens attitudes such as public grading the police work in their community, citizens readiness and participation to help law enforcement.

Therefore, police organizations make effort to ensure public support because public support allows the organizations to legitimize themselves. Officers' general thought of public support is affected not just by their individual interaction with people, but the police organization's experience of society (Lim et al. 2000). Police establishment relations with the public upset officers' awareness of public support (Nalla et al. 2014). Generally, people don't approach police because they're afraid of officers' coercive energy or police suspicious attitudes toward people, or police see that people don't trust them (Yim and Schafer, 2009). Officers' awareness of public support is directly connected with their attitudes toward community policing. Officials who thought that they are perceived more positively by people reported positive attitudes toward community policing (Boke and Nalla, 2009; Lord and Friday, 2008; Yim and Schafer, 2009).

\section{Theoretical Framework}

Job characteristic model and Expectancy motivation theory

This sudy combines two frameworks to test the commitment of police officers towards community policing in malaysia: one major and the other supporting. The main frame of this study is the job characteristics model. The job characteristics model tests how job characteristics influence officers' attitudes toward community policing as well as their job satisfaction. Expectancy motivation theory is uterlized to magnify the job characteristics model. In addition, expectancy motivation theory enables the exploration of the various aspects of job satisfaction. Job satisfaction is not unidimensional, but multi-dimensional.

In addition, employees' attitudes toward their tasks depend on how they perceive their job. In sum, job characteristics such as top management support and supervision influence employees' job satisfaction as well as their attitudes toward their tasks. Police organizations have two distinct facets of job characteristics. They have their own features, such as uncertainty, endangerments, and tough authority, which developed distinctively from the organizational situation (Crank, 2004; Paoline et al. 2000). In spite of such features that are exceptional to police work, police organizations also share wide-ranging and common characteristics with other organizations (Crank, 2004). 
In a police organization, organizational culture can be divided into two parts: top management support and communication with top managers (Adams et al. 2002). The job characteristics model suggests that top management support and communication influence officers' attitudes toward community policing as well as their job satisfaction. The positive perceptions of organizational culture lead to officers' high levels of job satisfaction and their positive attitudes toward community policing, Organizational culture can be found in all centralized policing systems.

Occupational culture comes from the unique characteristics of a police organization and its tasks and thus can be called police culture. Based on the literature review, nature of work, supervision, social network at work, and public support are considered to be the primary elements of occupational culture (Chan, 1997; Crank, 1997; Moon and Zager, 2007). According to the job characteristics model, it is assumed that nature of work, supervision, social network at work, and public support affect officers' attitudes toward community policing and their job satisfaction.

\section{Expectancy Motivation Theory}

Expectancy theory has held a major position in the study of work motivation. It proposes that a person will decide to behave in a certain way or have particular attitudes toward their tasks because they are satisfied with their expectations (for rewards, etc.). Vroom (1964) hypothesized that employee's job performance is a function of the interaction between their satisfaction and ability. Porter and Lawler (1968) presented a theoretical treatment of motivation to perform. They contended that motivated or satisfied employees are more likely to make efforts to improve their performance or positive attitude toward their tasks. The fulfillment of employees' expectation is one of the important factors that influence employees' performance and determine their attitudes toward the tasks. Over the past fifty years, expectancy motivation theory has been applied in many fields such as education (Schmitt and Son, 1981), healthcare (O' Sullivan et al. 2008; Seybolt and Pavett, 1979), and the private sector (Fudge and Schlacter, 1999). Expectancy motivation theory is also applied in policing (DeJong et al. 2001; Johnson, 2009; Mastrofski et al. 1994). Expectancy motivation theory suggests that officers' job satisfaction affects their attitudes toward their tasks. Officers' job satisfaction is measured by three factors (i.e., pay/benefits, promotion, and work). In this particular study, top management support and communication with top management is summed up as "management support", "social network at work is summed as "co-worker support" while public support is summed as "community support" and officer job satisfaction is taken as "job satisfaction". 
INTERNATIONAL JOURNAL OF ACADEMIC RESEARCH IN BUSINESS AND SOCIAL SCIENCES

Vol. 11, No. 15, Empowering Youth and Community Wellbeing for Sustainable Development, 2021, E-ISSN: 2222-6990 @ 2020 HRMARS

\section{Summary of operational definition of variables}

\begin{tabular}{|l|l|}
\hline Commitment & $\begin{array}{l}\text { A stabilizing force that acts to maintain behavioural direction when } \\
\text { expectancy/equity conditions are not meet and do not function (Scholl, 1981) }\end{array}$ \\
\hline $\begin{array}{l}\text { Management } \\
\text { support }\end{array}$ & $\begin{array}{l}\text { As an art of getting things done through and with people in organized group } \\
\text { (Koontz, 1980) }\end{array}$ \\
\hline $\begin{array}{l}\text { Job } \\
\text { Satisfaction }\end{array}$ & $\begin{array}{l}\text { Signifies hoe contented an individual is with his job. Spaecifically, it is a } \\
\text { multidimentional subjective construct representing an overall emotional feeling } \\
\text { individuals have about their job as a whole (Kalleberg, 1977) }\end{array}$ \\
\hline $\begin{array}{l}\text { Community } \\
\text { support }\end{array}$ & $\begin{array}{l}\text { community:a group of people with diverse characteristics who are linked by social } \\
\text { ties, common perspective and engage in joint action in geographical location or } \\
\text { setting (MacQueen et al., 2001). } \\
\text { Support: to approve of an idea or of a person or organization and help them to } \\
\text { be successful }\end{array}$ \\
\hline $\begin{array}{l}\text { Co-worker } \\
\text { support }\end{array}$ & $\begin{array}{l}\text { Co-worker: co worker is someone with whom you work or work alongside at your } \\
\text { job (Webster's, 2010). } \\
\text { Support: to approve of an idea or of a person or organization and help them to } \\
\text { be successful (Macmillan, 2013) }\end{array}$ \\
\hline
\end{tabular}

\section{Methodology}

Scale Item Development

Based on scale development procedures by Churchill (1979), there are eight step for researcher to follow sequently before the instruments is ready to used (1. Specify domain of construct; 2. Generate sample of items; 3. Collect data; 4. Purify measure; 5. Collect data; 6. Assess reliability; 7. Assess validity and; 8. Develop norms). In the current study, researcher start by conducting indepth interviews and two focus group discussion with police personnel from different background, rank and job specialization. Its important to understand more on police situation, implementation and views about the program. Then, researcher cross check with literature to develop a suitable instrument giving specific attention to culture and value orientation of Malaysia society. In the end, an instrument was developed of approximately 45 items, four reviewers enlisted by the researcher (i.e., Deputy Superintendent, Officer of Chief Station, Academician and Head of Community) to screen and evaluate the items. After two times item improvement, the judges confirmed the content validity and approved that the instrument is ready for pilot test.

The instrument comprises demographic information and 4 major independent variables namely Job satisfaction, co-worker support, Management support and community support; while the dependent variable, commitment was measured as representing both strategy and organizational commitment using Reichers (1985) multiple-foci approach as utilized by Ford et al. (2003). 6 questions were asked under strategy commitment and 7 items under organizational commitment, however only 10 item have been adapted based on current context of study. Officer job satisfaction towards community policing was measured using a modified version of 20 item short-form questions identified by Spector (1997). From the Minnesota job satisfaction questionnaire (MSQ) developed by Weiss and friends (1967), in Chughtai and Zafar, (2006), twelve items were selected out of twenty to test police officers satisfaction with community policing work. Community support questions were adopted from the Perceived community support questionnaire (PCSQ) of Lin, Dumin and Woelfel (in Herroro and Gracia, 2007). The measured include three different scales accessing three dimensions of community 
support (14 items): Community integration, community participation and community organization. The questions were tuned towards serving the purpose of community policing and community support. In this study, management support and co-worker support were measured adopted from Reichers (1985) Multiple-Foci Approach (Ford, 2007) consisting of six selected questions for management support and eleven questions for co-worker support.

\section{Data Collection}

This paper is part of a larger project that studies the community policing program in Malaysia targeting police organization (800 respondents) and community residences (500 respondents). For the police organization study, this pilot project adopted the survey method through administration of questionnaire on police officers involved in community policing from three districts of Alor Gajah, Jasin and Malacca Tengah in the state of Melaka, Malaysia. A total of 200 police officers range in rank from constables, inspectors and senior officers were choosen with the help of administrative officers within the police stations. It's believed that the respondents chosen have the potential to respond creditably well to meet the objective of the study. From that data gathering 197 respondents completed the questionnaire in the presence of the research team, while three questionnaires form were rejected because respondents submitted incomplete form. Theoretically, researcher can use as few as 50 to 200 sample is sufficient enough for validating instrument using survey method. However 200 and above sample often is recommended (Kline, 1998; Loehlin, 1998; Boomsma and Hoogland, 2001).

\section{Data Analysis (Reliability and validity test)}

The reliability of the instrument is measure toward which extent its free from random error, which also means the degree of consistency of a individual construct in instrument. By convention, the high alpha value $(=>.70)$ Cronbach is considered good and reliable. While validity means the extent to which a test measures what it claims to measure. It is vital for a test to be valid in order for the results to be accurately applied and interpreted. Amos software was used to conduct Construct Validity through Confirmatory Factor Analysis (CFA) in determining instrument that measure construct in this study. In Individual CFA analysis, Chi Square, GFA Index Value, CFI and RMSEA were applied. An instrument is considered reliable if the Chi Square value is low and its significance value is high (larger than .05), GFI index and CFI value must be larger than .9 and RMSEA value must be lower than .08, From Individual CFA also we examine the convergent validity for each construct in this study. Furthermore, we used measurement model for overall construct to test for overall model fit and also to check and to confirm on discriminant validity among each pairs of construct.

\section{Sample Profile}

Among 197 police personnel from Malacca state, $83.2 \%$ of the respondents were male and $16.8 \%$ were female; $31.0 \%$ were between the ages of 50 to 60 , while $43.2 \%$ were between the ages of 20 $40 ; 75.1 \%$ were married and $85.8 \%$ have at least completed high school education.

Most of them (80.0\%) were Muslim and identified as Malays. Interm of length of service in police department, almost all respondents have been at least three years experience in police work. 


\section{Result}

In this section, researcher reported three interesting finding based on Table 1 (convergence validity and reliability of the instrument through on Individual CFA) and Table 2 (discriminant validity and correlation co-effisyen).

\section{Individual CFA}

Based on Table 1, The results of assess the commitment construct indicated that the data fit the model: $\chi 2(5)=8.979, \mathrm{p}=0.110 \chi 2 / \mathrm{DF}=1.796 ; \mathrm{GFI}=0.983, \mathrm{CFI}=0.992, \mathrm{IFI}=0.992, \mathrm{RMSEA}=0.064$. The result also shown that several indices such GFI, CFI, and IFI significantly pass its cutoff value (0.9). Furthermore the result indicated that AVE for commitment construct is 0.598 , while CR is 0.878 .

The results of assess the job satisfaction construct indicated that the data fit the model: $\chi 2(9)=$ 23.646, $\mathrm{p}=0.005 \times 2 / \mathrm{DF}=2.627 ; \mathrm{GFI}=0.961, \mathrm{CFI}=.976, \mathrm{IFI}=.997, \mathrm{RMSEA}=0.091$. The GFI, CFI, and IFI significantly pass its cutoff value (0.9). In addition, The RMSEA was 0.091, which slightly higher then the recommended range (between 0.03 and 0.08). Next, the value for AVE is 0.583 , while CR was 0.893 .

The results of assess the co-worker support construct indicated that the data fit the model: $\chi 2(5)=$ 5.850, $\mathrm{p}=0.321 \times 2 / \mathrm{DF}=1.170 ; \mathrm{GFI}=0.988, \mathrm{CFI}=0.998, \mathrm{IFI}=0.998, \mathrm{RMSEA}=0.029$. The $\mathrm{GFI}, \mathrm{CFI}$, and IFI and significantly pass its cutoff value (0.9). The AVE result for this construct is 0.624 , while CR is 0.891.

The results of assess the management support construct indicated that the data fit the model: $\chi 2$ (5) $=2.654, p=0.753 \chi 2 / D F=0.531 ; \mathrm{GFI}=0.995, \mathrm{CFI}=1.000, \mathrm{IFI}=1.006, \mathrm{RMSEA}=0.000$. The $\mathrm{CFI}, \mathrm{IFI}$ and TLI significantly pass its cutoff value (0.9). In addition, The RMSEA was 0.000 , which slightly lower the recommended range (between 0.03 and 0.08 ). The AVE result for this construct is 0.522 , while CR is 0.844 .

The results of assess the community support construct indicated that the data fit the model: $\chi 2$ (14) $=20.248, \mathrm{p}=0.123 \chi 2 / \mathrm{DF}=1.446 ; \mathrm{GFI}=0.971, \mathrm{CFI}=0.991, \mathrm{IFI}=0.991, \mathrm{RMSEA}=0.048$. The CFI, IFI and TLI significantly pass its cutoff value (0.9). Furthermore the result indicated that AVE for community support construct is 0.565 , while CR is 0.900 . 
INTERNATIONAL JOURNAL OF ACADEMIC RESEARCH IN BUSINESS AND SOCIAL SCIENCES

Vol. 11, No. 15, Empowering Youth and Community Wellbeing for Sustainable Development, 2021, E-ISSN: 2222-6990 @ 2020 HRMARS

Table 1: Average Variance Extracted and construct Reliability of Study Instruments

\begin{tabular}{|c|c|c|c|c|c|}
\hline Construct & & $\begin{array}{l}\text { Original item } \\
\text { prepared }\end{array}$ & $\begin{array}{l}\text { Final No. } \\
\text { of Items }\end{array}$ & $\begin{array}{l}\text { Ave.Variance } \\
\text { Extracted } \\
\text { (AVE) } \\
\end{array}$ & $\begin{array}{l}\text { Construct } \\
\text { Reliability } \\
\text { (CR) } \\
\end{array}$ \\
\hline Commitment & (C) & 10 & 5 & 0.598 & 0.878 \\
\hline Job Satisfaction & (JS) & 9 & 6 & 0.583 & 0.893 \\
\hline $\begin{array}{l}\text { Co-Worker } \\
\text { Support }\end{array}$ & (CWS) & 9 & 5 & 0.624 & 0.891 \\
\hline $\begin{array}{l}\text { Management } \\
\text { Support }\end{array}$ & (MS) & 6 & 5 & 0.522 & 0.844 \\
\hline $\begin{array}{l}\text { Community } \\
\text { Support }\end{array}$ & (CS) & 11 & 7 & 0.565 & 0.900 \\
\hline & Total & 45 & 28 & - & - \\
\hline
\end{tabular}

Measurement Model

To demonstrate that multiple measures of a construct are related, test for measurement model was used. Researchers also use the measurement model to examine the extent of interrelationships and covariation (or lack thereof) even when the two measurement methods are similar among the constructs. In other words, convergent and discriminant validity require that multiple measures of a construct relate highly to each other and less highly to measures of other constructs. The result for overall measurement model in Table 2 potray that the data fit the model: $\chi 2(340)=718.643, p=$ $0.000 \times 2 / \mathrm{DF}=2.114 ; \mathrm{GFI}=0.800, \mathrm{CFI}=0.892, \mathrm{IFI}=0.893, \mathrm{RMR}=0.029$, and $\mathrm{RMSEA}=0.075$. Several indices such GFI, CFI, and IFI were little bit lower but acceptable because its approaching the cutoff value 0.9 . While for the discriminant validity purpose, all construct's AVE were found more higher than Squared Correlation Coefficients for each pairs.

Table 2: Average Variance Extracted (On the Diagonal) and Squared Correlation Coefficients (on the Off diagonal) for study Instruments

\begin{tabular}{llllll}
\hline \hline & JS & CWS & MS & CS & C \\
\hline \hline JS & & & & & \\
CWS & $\mathbf{0 . 5 8 3}$ & & & & \\
MS & 0.372 & $\mathbf{0 . 6 2 4}$ & & & \\
CS & 0.476 & 0.410 & $\mathbf{0 . 5 2 2}$ & & \\
C & 0.397 & 0.325 & 0.410 & $\mathbf{0 . 5 6 5}$ & \\
& 0.563 & 0.185 & 0.372 & 0.221 & $\mathbf{0 . 5 9 8}$ \\
\hline \hline
\end{tabular}

\section{Discussion}

The purpose of this research was to construct and validate a brief measure commitment towards community policing program from the perspective of police officer. This research has been invaluable for Malaysian context because it's rare to find reports regarding police commitment in program related to community engagement especially community policing and this research also exploring 
several factors which influence officer commitment. We tested the psychometric properties of the self-report survey among a diverse sample of police officer who work along with community.

In every research process, integrity on the measurement used was significantly important. Therefore, validating and determining the consistency of the instrument especially related to constructs in each study will acknowledge the quality of the instrument. In this study, researcher believed that we do follow the step suggest by Churchill (1979), therefore the process of instrument development should be genuine. Researcher confirm that all constructs was defined carefully based on literature specifically on commitment study, then we designed it to the Malaysian context through series of dialogue with practitioners and police on the ground. Then, researcher develop items for each constructs depending on previous instruments so that we are parrellel with other studies.

The findings from individual CFA based on Table 1, was confirm to be valid and reliable. All construct's AVE was more than .50 and the construct reliability was more than .70. Therefore, its assured that the construct's item was converge and measure what it supposed to measure. Confirmatory factor analyses of the full model demonstrated good fit for the model. The final statement of commitment revealed good internal consistency. In particular to Table 2, the results for discriminant validity was shown that all construct was differ among others. Discriminant validity of the construct measures was demonstrated with other factors including Job Satisfaction (JS), Co-Worker Support (CWS), Management Support (MS) and Community Support (CS). In all cases, variance extracted estimates (AVE) were greater than the squared correlation estimates for each pair of constructs. This is important indication that each construct did not represent or interfere on other construct in the study (Cook and Campbell, 1979). Finally, concurrent validity was demonstrated through moderate and positive correlations between construct. Generalizability is further suggested through the inclusion of an adequate sample drawn from one state in Malaysia.

Its important to highlight about the reduce of number of item from the original measure among each construct in the current study. We refer our item reduction base on the two source, a) low factor loading while examine the individual CFA in specific construct, b) item in the original instrument was not suitable for Malaysian police context through series of examination with evaluator which mention in the section methodology.

\section{Implications for Future Research}

Community policing is growing tremendously around the globe, while police department and police officers already bombarded with a lot of task in hand. However commitment towards the implementation of the program is crucial to create a safer environment in the country. We are optimist that this measure will help scholars build a comparable body of knowledge from research across different types of intervention in police organizational setting. The heterogeneity of the future sample is suggested using this measure. This is the first attempt to validate the newly created Commitment of Police Officers in Community Policing measure. Consequently, these results need to be replicated with other state or country and samples for further validation of the measure.

\section{Implications for Practice}

Increasing crime cases in the community always create a feeling of insecurity among public especially resident, which make the country in a great lose. Therefore the emergence of police department 
across the globe implementing Community Policing can be seen as a sign for improvement toward nation building. It is becoming a normative expectation in the country that police should share their knowledge and expertise in crime prevention and managing crime in locality. Besides other roles and commitment, Police officers must engage with public through community organization and selected government based programs aimed at engaging public especially residence association and their resident's member in promoting and educate the local people about crime prevention including organizational governance and program planning, and evaluation. Understanding this measure, will help all stakeholder especially in the police organizational including the top management, co-worker, policy maker, and community in improving the quality of the job provide by officers.

The construct in the present study, we hope, will be useful by offering a tool that will help operationalize of police officers commitment and several influential factors to inform policy development, program planning and continuous improvement efforts.

\section{Conclusion}

Researcher have confirm the instrument of the current study was valid and reliable, so that the bigger study and data collection with bigger population can be proceed using the instrument. In light to the policing strategy, its complementary to have community policing program in crime prevention in Malaysia.

\section{References}

Adams, R. E., Rohe, W. M., \& Arcury, T. A. (2002). Implementing community-oriented policing: organizational change and street officer attitudes. Crime and Delinquency, 48(3), $399-430$.

Bayley, D. H. (1994). Police for the Future. Oxford University Press on Demand.

Boke, K., \& Nalla, M. K. (2009). Police organizational culture and job satisfaction: A comparison of law enforcement officers' perceptions in two Midwestern States in the U.S. Journal of Criminal Justice and Security, 11(1), 55-73.

Boomsma, A., \& Hoogland, J. J. (2001). The robustness of LISREL modeling revisited. Structural equation models: Present and future. A Festschrift in honor of Karl Jöreskog, 2(3), 139-168.

Brunetto, Y. \& Farr-Wharton, R. (2003), "The commitment and satisfaction of lower-ranked police officers: Lessons for management", Policing: An International Journal, 26(1), 4363. https://doi.org/10.1108/13639510310460297

Chan, J. B. (1997). Changing police culture: Policing in a multicultural society. Cambridge University Press.

Chughtai, A. A., \& Zafar, S. (2006). Antecedents and Consequences of Organizational Commitment Among Pakistani University Teachers. Applied H.R.M. Research, 11(1), 39-64.

Churchill, G. (1979). A paradigm for developing better measures of marketing constructs. Journal of Marketing Research, 16 (February), 64-73.

Cohen, A. (2003). Multiple commitments in the workplace: An integrative approach. Mahwah, NJ: Lawrence Erlbaum Associates.

Cooper-Hakim, A., \& Viswesvaran, C. (2005). The construct of work commitment: Testing an integrative framework. Psychological Bulletin, 131(2), 241-259.

Crank, J. P. (1997). Celebrating agency culture: Engaging a traditional cop's heart in organizational change. In Q. C. Thurman \& E. McGarrell (Eds.),Community policing in a rural

Crank, J. P. (2004). Understanding Police Culture (2 nd Eds). Cincinnati, OH: Anderson. 
Engel, R., \& Worden, R. (2003). Police Officers' attitudes, behavior, and supervisory influences: an analysis of problem solving. Criminology, 41(1), 131-166.

Ford, J. K., Weissbein, D. A., \& Plamondon, K. E. (2003). Distinguishing organizational from strategy commitment: Linking officers' commitment to community policing to job behaviors and satisfaction. Justice Quarterly, 20, 159-185.

Ford, J. K. (2007). "Building capability throughout a change effort: leading the transformation of a $p$ olice agency to community policing." American journal of community psychology, 393-4.

Fudge, R. S., \& Schlacter, J. L. (1999). Motivating employees to act ethically: An expectancy theory approach. Journal of Business Ethics, 18(3), 295-304.

Gonzalez, T. M., \& Guillen, M. (2008). Organizational commitment: A proposal for a wider ethical conceptualization of normative commitment. Journal of Business Ethics, 78, 401-414.

Greene, J. R. (2000). Community policing in America: changing the nature, structure, and function of the police. Criminal Justice, 299-370.

Haley-Lock, A. (2007). Up close and personal: employee networks and job satisfaction in a human service context. Social Service Review, 81 (4), 683-707.

Halsted, A. J., Bromley, M. L., \& Cochran, J. K. (2000). The effects of work orientations on job satisfaction among sheriffs' deputies practicing community oriented policing. Policing: An International Journal of Police Strategies \& Management, 23(1), 82-104.

Herrero, J., \& Garcia, E. (2007). Measuring perceived community support: Factorial structure, longitudinal invariance, and predictive validity of the PCSQ (Perceived Community Support Questionnaire). Journal of Community Psychology, 35(2), 197-217.

Hwang, U., \& Woo, Y. (2009). Factors Affecting Supportive Attitudes and Field Activities of Community Oriented Policing among Police Officers. Journal of Korean Police, 8(1) 3.

Johnson, S. D., Koh, H. C., \& Killough, L. N. (2009). Organizational and Occupational Culture and the Perception of Managerial Accounting Terms: An Exploratory Study Using Perceptual Mapping Techniques. Contemporary Management Research, 5(4), 317-342.

Kalleberg, A. L. (1977). Work values and job rewards: A theory of job satisfaction. American sociological review, 124-143.

Kline, P. (1998). The new psychometrics: Science, psychology, and measurement. Psychology Press.

Koontz, H. (1980). The management theory jungle revisited. Academy of management review, 5(2), 175-188.

Kristof-Brown, A. L., Zimmerman, R. D., \& Johnson, E. C. (2005), “Consequences of individuals' fit at work: A meta-analysis of person-job, person-organization, person-group and personsupervisor fit", Personnel Psychology, 58, 281-342.

Kwak, H. (2009). Performance evaluation of community policing: The application of Balanced Score Card (BSC). Unpublished dissertation. Kyungnam, Korea: Youngnam University.

Lilley, D., \& Hinduja, S. (2007). Police officer performance appraisal and overall satisfaction. Journal of Criminal Justice, 35, 137-150

Lim, V.K., Teo, T., \& See, S.K. (2000). Perceived job image among police officers in Singapore: Factorial dimensions and differential effects. Journal of Social Psychology, 140(6), 740-750.

Loehlin, J. M. (1998). Latent variable models (3rd ed.). Hillsdale, NJ: Lawrence Erlbaum Associates, Inc Lord, V. B., \& Friday, P.C. (2008). What Really Influences Officer Attitudes Toward COP? The Importance of Context. Police Quarterly, 11(2), 220-38.

Lucas, W., Novak, K., \& Alarid, L. (2003). Exploring officers' acceptance of community policing: Implications for policy implementation. Journal of Criminal Justice, 31(1), 57-71. 
INTERNATIONAL JOURNAL OF ACADEMIC RESEARCH IN BUSINESS AND SOCIAL SCIENCES

Vol. 11, No. 15, Empowering Youth and Community Wellbeing for Sustainable Development, 2021, E-ISSN: 2222-6990 @ 2020 HRMARS

Macmillan, R. (2013). Making sense of the Big Society: perspectives from the third sector.

MacQueen, K. M., McLellan, E., Metzger, D. S., Kegeles, S., Strauss, R. P., Scotti, R., ... \& Trotter, R. T. (2001). What is community? An evidence-based definition for participatory public health. American journal of public health, 91(12), 1929-1938.

Mastrofski, S. D., Ritti, R. R., \& Snipes, J. B. (1994). Expectancy theory and police productivity in DUI enforcement. Law and Society Review, 113-148.

Meyer, J. P., \& Herscovitch, L. (2001). Commitment in the workplace: toward a general model. Human Resource Management Review. 11, 299-326

Moon, B. (2006). The Influence of Organizational Socialization on Police Officers' Acceptance of Community Policing. Policing: An International Journal of Police Strategies \& Management, 29(40), 704-722.

Moon, B., \& Zager, L. J. (2007). Police officers' attitudes toward citizen support: Focus on individual, organizational and neighborhood characteristic factors. Policing: An International Journal of Police Strategies \& Management, 30(3), 484-497.

Nalla, M. K., Modic, M., \& Meško, G. (2014). Community Policing Reforms and Organizational Changes: An Assessment of Officers' Perceptions of Community-Police Relations in Slovenia. Revija za kriminalistiko in kriminologijo, 65(4), 272-286

O'Sullivan, B., McGee, H., \& Keegan, O. (2008). Comparing solutions to the 'expectancy-value muddle' in the theory of planned behaviour. British Journal of Health Psychology, 13(4), 789-802.

Paoline, E. A., Myers, S. M., \& Worden, R. E. (2000). Police Culture, Individualism, and Community Policing: Evidence From Two Police Departments. Justice Quarterly, 17(3), 575- 605.

Park, K. (2006). What factors do explain the citizen orientation of street-level police? Korean Journal of Public Administration, 44(2), 113-148.

Pelfrey, W. V. (2007). Style of policing adopted by rural police and deputies: An analysis of job satisfaction and community policing. Policing: An International Journal of Police Strategies \& Management, 30(4), 620-636.

Pelfrey, W. V. (2004). The inchoate nature of community policing: Differences between community policing and traditional police officers. Justice Quarterly, 21(3), 579-601.

Peterson, A., \& Uhnoo, S. (2012). Trials of loyalty: Ethnic minority police officers as 'outsiders' within a greedy institution. European journal of criminology, 9(4), 354-369.

Polzin, M. J., \& Brockman, J. (2002). Focus on internal partnerships: A framework for implementing community policing in a unionized department". In M. Morash and J. K. Ford (Eds.), The move to community policing: Making change happen. Thousand Oaks, CA: Sage Publications.

Porter, L. W., \& Lawler, E. E. (1968). Managerial attitudes and performance.

Reichers, A. E. (1985). A review and reconceptualization of organizational commitment. Academy of management review, 10(3), 465-476.

Rhoades, L., \& Eisenberger, R. (2002). Perceived organizational support: a review of the literature. Journal of applied psychology, 87(4), 698.

Schmitt, N., \& Son, L. (1981). An evaluation of valence models of motivation to pursue various post high school alternatives. Organizational behavior and human performance, 27(1), 135-150.

Scholl, R. W. (1981). Differentiating organizational commitment from expectancy as a motivating force. Academy of management Review, 6(4), 589-599.

Seybolt, J. W., \& Pavett, C. M. (1979). The prediction of effort and performance among hospital professionals: Moderating effects of feedback on expectancy theory formulations. Journal of Occupational Psychology, 52(2), 91-105. 
Somers, M., \& Birnbaum, D. (2000). Exploring the relationship between commitment profiles and work attitudes, employee withdrawal, and job performance. Public Personnel Management, 29(3), 353-366.

Spector, P. E. (1997). Job satisfaction: Application, assessment, causes, and consequences (Vol. 3). Sage.

Sulaiman, A. H., Othman, J., Samah A. B., Yero, A., D'Silva, J. L., Ortega, A. (2014). Determinants of community participation in community policing program in Malaysia. Journal of Applied Sciences. 14(20), 2439-2449.

Sutham, C., \& Sarit, P. (2005). Service Culture for the Implementation of Community Policing: A Case Study of the Malaysian Police. Journal International Journal of Police Science \& Management, $7(4), 286-299$

Tankebe, J. (2010). Identifying the correlates of police organizational commitment in Ghana. Police Quarterly, 13(1), 73-91.

Tilley, N. (2003). Community policing, problem-oriented policing and intelligence-led policing. In T. Newburn (ed.), Handbook of Policing. Cullompton, Devon: Willan.

Vroom, V. H. (1964). Work and motivation.

Webster's New World College Dictionary Copyright. (2010) Wiley Publishing, Inc., Cleveland, Ohio.

Weiss, D. J., Dawis, R. V., \& England, G. W. (1967). Manual for the Minnesota satisfaction questionnaire. Minnesota studies in vocational rehabilitation.

Wilson, D. G., \& Bennett, S. F. (1994). Officers' response to community policing: Variations on a theme. Crime \& Delinquency, 40(3), 354-370.

Wuthichai, T. (2017). Factors affecting the effectiveness of police performance in Metropolitan Police Bureau. Kasetsart Journal of Social Sciences, 38(1), 39-44, 10.1016/j.kjss.2016.07.001.

Yim, Y., \& Schafer, B. D. (2009). Police and their perceived image: How community influence officers' job satisfaction. Police Practice \& Research, 10(1), 17- 29.

Young, R., \& Jordan, E. (2008). Top management support: Mantra or necessity? International Journal of Project Management, 26(7), 713-725. 